\title{
OTTO GOTLLIEB, UM CIENTISTA À FRENTE DE SEU TEMPO
}

Convidadas a escrever o Editorial deste Número Especial de Química Nova dedicado ao grande mestre e cientista, Professor Otto Richard Gottlieb, dois sentimentos emanaram de imediato. O primeiro, de alegria e orgulho por termos recebido a nobre missão de historiar a vida científica do nosso querido orientador. O segundo veio logo a seguir - o peso de escrever, em poucas linhas, sobre um dos maiores cientistas brasileiros, responsável pela Química de Produtos Naturais moderna que se faz hoje no país.

Condensar em uma página suas ideias, criatividade e a grandiosidade de sua contribuição científica é um exercício de responsabilidade mas, ao mesmo tempo de contentamento, dada a admiração e o carinho pelo nosso orientador e mentor, o maior fitoquímico da América Latina do século XX. Resumir em poucas linhas sua vida acadêmica e pessoal é quase impossível, devido ao legado científico inestimável que deixou para o país que escolheu como pátria e para a pesquisa em Química de Produtos Naturais. A diversidade e o vigor da pesquisa nesta área estão traduzidas em mais de 700 publicações, grande parte dedicada ao entendimento da biodiversidade vegetal brasileira, refletem-se hoje nas pesquisas realizadas por seus filhos, netos e bisnetos científicos.

A variedade de temas de vanguarda sobre a Química de Produtos Naturais, como era seu sonho, é hoje uma realidade nas investigações dos atuais pesquisadores da área, que atuam em tópicos de biologia molecular, biossíntese, proteoma, metaboloma, técnicas hifenadas de última geração envolvendo HPLC, EM e RMN, tendo como essência a associação da Química e da Biologia, objetivando o entendimento e o funcionamento dos sistemas biológicos.

O cientista Otto ficou conhecido também como o professor itinerante. Ministrando aulas de Química Orgânica e de Produtos Naturais, Métodos Espectrométricos de EM e RNM em todo o país, estruturou a maioria dos grupos de produtos naturais vigentes nas cinco regiões brasileiras. Detentor de uma didática espetacular, suas aulas e conferências eram magníficas. Discorria sobre química e filogenia de plantas com uma eloquência particular, encantando seus alunos, professores e pesquisadores. Apaixonado pela natureza, em especial pelo universo molecular das plantas, reformulou a quimiossistemática vigente e estabeleceu novas bases para a taxonomia. Usando índices numéricos para quantificar metabólitos secundários, estabeleceu mapas filogenéticos usando a quantificação de praticamente todas as classes de metabólitos secundários.
Com isso, diagnosticou e estabeleceu importantes tendências filogenéticas em vários táxons, fundamentais para o entendimento funcional das plantas em seus respectivos ecossistemas. À frente de seu tempo, vemos hoje, suas ideias e conceitos sendo aplicados no entendimento molecular da biodiversidade, traduzidos nos avanços das pesquisas realizadas sobre a biologia molecular de plantas, essenciais ao entendimento da engrenagem funcional dos organismos de um determinado ecossistema. Associar características fenotípicas ao genótipo e, ao mesmo tempo, inferir uma perfeita sintonia entre o metaboloma/proteoma (micro- e macromoléculas), foi a base de cerca de $50 \%$ de seu trabalho experimental e teórico publicado em vários periódicos da área. A química de produtos naturais de vanguarda feita atualmente em países centrais objetiva entender o funcionamento molecular dos sistemas biológicos, um foco já evidente em várias publicações. Em 1992, publicou na Química Nova ${ }^{1}$ um belíssimo artigo de revisão sobre "Biodiversidade: uma teoria molecular", onde enfatizava a importância das reações de transferências de elétrons em sistemas redox essenciais à evolução das Angiospermas, reafirmado no artigo de Falkowski².

Fizemos nossas teses de doutorado sob sua orientação, trabalhando a quimiotaxonomia de Rutales e de Gentianales. Já ao término das nossas teses, o Professor Otto apresentava os primeiros sinais do Mal de Parkinson, mas seu brilho e magnetismo ao defender suas ideias disfarçavam a doença, sem cura eficaz até aos dias atuais. Sua paixão pelo que fazia e pela diversidade química que acreditava ser a base para o entendimento da complexa engrenagem metabólica da biodiversidade era tão fascinante que assegurava - "Cada planta tem centenas de substâncias e uma delas pode ser mais importante do que uma galáxia". Sua obra transcende seus mais de 700 artigos, vários livros e algumas patentes sobre lignanas e neolignanas de Lauraceae e Myristicaceae.

\section{Maria Fátima das Graças Fernandes da Silva Departamento de Química, UFSCar Vanderlan da Silva Bolzani Instituto de Química, UNESP}

\section{REFERÊNCIAS}

1. Gottlieb, O. R.; Quim. Nova 1992, 15, 167.

2. Falkowski, P. G.; Science 2006, 311,1724. 